\title{
Gender Difference in the Association Between Serum Uric Acid Level and Metabolic Syndrome and Components: A Cross-Sectional Analysis Among Chinese Young Adults
}

\author{
Zhengmei Fang \\ Wannan Medical College \\ Yan Chen \\ Wannan Medical College \\ Lijun Zhu \\ Wannan Medical College \\ Lianping He \\ Taizhou University \\ Yuelong Jin \\ Wannan Medical College \\ Yingshui Yao ( $\nabla$ yingshuiyao@126.com ) \\ Wannan Medical College
}

Research article

Keywords: abdominal obesity, metabolic syndrome, uric acid, high blood pressure, dyslipidemia

Posted Date: February 2nd, 2021

DOI: https://doi.org/10.21203/rs.3.rs-155347/v1

License: () (1) This work is licensed under a Creative Commons Attribution 4.0 International License. Read Full License 


\section{Abstract \\ Background}

This study aimed to investigate the associations between serum uric acid (SUA) levels and metabolic syndrome (MetS) and MetS components in Chinese young adults.

\section{Methods}

A cross-sectional survey was conducted among 3044 young adults (1266 men and 1778 women). The anthropometric index, lipid profile, fasting blood glucose and SUA levels were measured. Male and female participants were grouped according to the quartiles of SUA level separately. Multiple logistic regression analyses were performed to evaluate the association of SUA quartiles with MetS and its components.

\section{Results}

The overall prevalence of hyperuricemia and MetS was $29.7 \%$ and $2 \%$, respectively. Multiple logistic regression analysis revealed that compared with the lowest 2 quartiles of SUA together, the highest quartile showed an association with the prevalence of MetS and high triglyceride in males, and OR $(95 \% \mathrm{Cl})$ were $3.438(1.090$ $10.841)$ and 4.364(2.133-8.930) respectively after adjustments confounding factors. In terms of abdominal obesity, compared with the lowest 2 quartiles of SUA together, the OR $(95 \% \mathrm{Cl})$ was $1.976(1.128-3.459)$ for those in the third quartile and 1.766(1.020-3.057) for those in the highest quartile after adjustments confounding factors in females.

\section{Conclusions}

This study suggested a significant positive relationship between SUA and MetS and its components among young adults. Hence, routine measurement of SUA is recommended to prevent hyperuricemia and its related complications.

\section{Background}

Metabolic syndrome (MetS) is an increasing public health problem, including general or central adiposity, high blood pressure, hyperglycemia, and dyslipidemia ${ }^{1}$. The prevalence rates of MetS in China were $9.8 \%$ in men and $17.8 \%$ in women based on a survey conducted in $2000-2001^{2}$ and the rates increased to $31.0 \%$ and $36.8 \%$, respectively ${ }^{3}$. Epidemiological studies have reported that MetS with individual component is involved in various chronic diseases, such as cardiovascular diseases ${ }^{4}$, diabetes ${ }^{5}$ and cancers ${ }^{6}$. Therefore, early intervention for MetS components is necessary to prevent the development of related diseases and reduce the public health burden worldwide.

Uric acid (UA) is the ultimate metabolite of purine compounds. Previous studies have shown that uric acid, as one of the strong antioxidants, can provide some type of protection against cell oxidative damage. However, 
overproduction or underexcretion of uric acid can lead to adverse consequences, such as hyperuricemia and gout, which contribute to essential disease burden and health loss ${ }^{7}$. Previous epidemiological studies have found an association of increased serum uric acid (SUA) levels and MetS in different populations ${ }^{8-10}$. Furthermore, studies have demonstrated that increased SUA level is an important marker for predicting the risk of developing MetS components, such as hypertension ${ }^{11}$, diabetes ${ }^{12}$, obesity ${ }^{13}$, and dyslipidemia ${ }^{14}$. Our previous study found that a significantly increasing trend existed in the body mass indices (BMI) across the SUA level quartiles $\left(23.8 \mathrm{~kg} / \mathrm{m}^{2}, 24.8 \mathrm{~kg} / \mathrm{m}^{2}, 26.2 \mathrm{~kg} / \mathrm{m}^{2} \text {, and } 30.1 \mathrm{~kg} / \mathrm{m}^{2}\right)^{15}$. However, most studies have focused on this relationship in adults.

It has been documented that lifestyle in early life may be a strong predictor of uric acid metabolism and the resulting disease risk ${ }^{16}$. Given the increased prevalence of MetS in the Chinese young adults, this study aimed to further evaluate the relationships between SUA and MetS components, including dyslipidemia, hypertension, and obesity among Chinese young adults.

\section{Methods}

\section{Sample and procedure}

This study was conducted from September to November 2018, all 3450 young adults from a medical school participated in the physical examination, with 3430 students participating in the survey (response rate: $99.42 \%)$. Excluded subjects were those who less than 18 years old $(n=300)$, or missed height or weight $(n=86)$, finally, 3044 eligible subjects were included in the final analyses. The self-administrated questionnaire was completed by trained interviewers with demographic characteristics of gender, age, smoking and drinking status, physical activity, etc.

\section{Anthropometric measurement}

All participants received physical examinations; weight, height, waist circumference (WC), hip circumference (HC) and blood pressure were measured. The measurements were obtained from each participant by trained staff according to a standard protocol. Height, WC and HC were measured to the nearest $0.1 \mathrm{~cm}$ and weight to the nearest $0.1 \mathrm{~kg}$ by ultrasound height and weight measuring instrument (Shengyuan, China). Subjects were measured in socks or bare feet and light clothes. WC was measured $1 \mathrm{~cm}$ above the umbilicus in a horizontal plane. $\mathrm{HC}$ was measured at the level of the maximal gluteal protrusion by using general tape. Waist-hip ratio (WHR) was calculated as WC divided by HC. Blood pressure was measured 2 times by Omron U30 electronic sphygmomanometer in the seated position after at least 5 minutes of rest and their average value was obtained for analysis. Obesity was defined according to body mass index (BMl; weight (kg)/height (m) ${ }^{2}$ ) based on Chinese-specific criteria ${ }^{17}$. Accordingly, normal weight or underweight was defined as $\mathrm{BMl}<23.9 \mathrm{~kg} / \mathrm{m}^{2}$, overweight as BMI of $24-27.9 \mathrm{~kg} / \mathrm{m}^{2}$ and obesity as $\mathrm{BMI} \geq 28 \mathrm{~kg} / \mathrm{m}^{2}$. At least 30 minutes duration of exercises per day, that caused heavy sweating or large increases in breathing or heart rate, was defined as physical activity ${ }^{18}$. High physical activity was defined as exercising 3 times or more per week.

\section{Laboratory measurements}


Blood samples were obtained from participants after 10 hours of overnight fasting. High-density lipoprotein cholesterol (HDL-C), low-density lipoprotein cholesterol (LDL-C), total cholesterol (TC), triglycerides (TG), SUA and fasting plasma glucose (FPG) were measured by enzymology in Hitachi 7170A automatic analyzer (Hitachi, Japan). Hyperuricemia was defined as SUA $\geq 416(\mu \mathrm{mol} / \mathrm{L})$ in males or $\geq 357(\mu \mathrm{mol} / \mathrm{L})$ in females ${ }^{19}$.

\section{Definition of MetS}

The definition of MetS was in accordance with the International Diabetes Federation and the American Heart Association criteria that the presence of any 3 of the following condition constitutes a diagnosis of MetS: WC for Asians $\geq 80 \mathrm{~cm}$ in women and $\geq 90 \mathrm{~cm}$ in men; systolic blood pressure(SBP) $\geq 130 \mathrm{mmHg}$ or diastolic blood pressure(DBP) $\geq 85 \mathrm{mmHg}$; FPG $\geq 100 \mathrm{mg} / \mathrm{dl} ; \mathrm{HDL}-\mathrm{C}<50 \mathrm{mg} / \mathrm{dl}$ in women and $<40 \mathrm{mg} / \mathrm{dl}$ in men; TG level $\geq 150 \mathrm{mg} / \mathrm{dl}^{20}$.

\section{Statistical analysis}

Continuous data were expressed by means \pm standard difference (SD) and categorical variables by percentage. T-test and one-way ANVOA were used in continuous data analysis. Categorical variables distributions were compared by the Chi-square test and trend Chi-square test. Correlation analysis between SUA and continuous variables of MetS components were assessed by Pearson's correlation coefficient test. Multivariable logistic regressions were performed to evaluate the association of SUA and MetS and components to calculate odds ratios (ORs) and its $95 \%$ interval confidence $(\mathrm{Cl})$. SPSS 18.0 was used for statistical analysis (SPSS, Inc, Chicago, IL), and a $P$ value $<0.05$ was defined to be statistically significant.

\section{Results}

\section{Baseline characteristics of this study}

A total of 3044 young adults were included in the final data analysis. The mean age of the participants was $18.69 \pm 0.95$ years (range 18-26 years). Of the 3044 subjects, $1778(58.41 \%)$ were females and the mean \pm SD) age was $18.68 \pm 0.95$ years. The prevalence of MetS, hyperuricemia and high physical activity in males was significantly higher than that in females $(P<0.05)$. The males had significantly higher BMI, WC, HP, WHR, SBP, DBP, LDL-C and FPG levels but significantly lower HDL-C and TC levels than the females $(P<0.05)$. The demographic characteristics of all participants are summarized in Table 1. 
Table 1

Demographic and clinical characteristics of this study

\begin{tabular}{|c|c|c|c|c|c|}
\hline Characteristic & $\begin{array}{l}\text { Both genders } \\
(n=3044)\end{array}$ & $\begin{array}{l}\text { Males } \\
(n=1266)\end{array}$ & $\begin{array}{l}\text { Females } \\
(n=1778)\end{array}$ & $t / x^{2}$ & $\mathbf{P}$ \\
\hline Age (year) & $18.69 \pm 0.95$ & $18.71 \pm 0.95$ & $18.68 \pm 0.95$ & 0.901 & 0.368 \\
\hline Height (cm) & $165.37 \pm 8.59$ & $172.94 \pm 6.04$ & $159.98 \pm 5.53$ & 60.37 & $<0.001$ \\
\hline Weight (kg) & $61.32 \pm 12.34$ & $69.16 \pm 12.55$ & $55.74 \pm 8.58$ & 32.969 & $<0.001$ \\
\hline $\operatorname{BMI}\left(\mathrm{kg} / \mathrm{m}^{2}\right)$ & $22.32 \pm 3.50$ & $23.11 \pm 3.93$ & $21.76 \pm 3.04$ & 10.251 & $<0.001$ \\
\hline WC (cm) & $72.70 \pm 9.00$ & $78.25 \pm 9.49$ & $69.47 \pm 7.02$ & 24.747 & $<0.001$ \\
\hline Abdominal obesity, n (\%) & $301(9.9)$ & $138(10.9)$ & $163(9.2)$ & 2.492 & 0.114 \\
\hline $\mathrm{HC}(\mathrm{cm})$ & $94.09 \pm 6.74$ & $96.30 \pm 7.27$ & $92.51 \pm 5.85$ & 15.372 & $<0.001$ \\
\hline WHR & $0.77 \pm 0.06$ & $0.80 \pm 0.05$ & $0.75 \pm 0.05$ & 26.323 & $<0.001$ \\
\hline SBP $(\mathrm{mmHg})$ & $114.07 \pm 13.74$ & $121.7 \pm 13.49$ & $108.64 \pm 11.08$ & 28.289 & $<0.001$ \\
\hline $\mathrm{DBP}(\mathrm{mmHg})$ & $71.03 \pm 10.56$ & $73.38 \pm 11.01$ & $69.35 \pm 9.89$ & 10.381 & $<0.001$ \\
\hline $\mathrm{TC}(\mathrm{mmol} / \mathrm{L})$ & $4.06 \pm 0.68$ & $4.02 \pm 0.74$ & $4.09 \pm 0.63$ & 2.851 & 0.004 \\
\hline $\mathrm{TG}(\mathrm{mmol} / \mathrm{L})$ & $0.83 \pm 0.40$ & $0.87 \pm 0.47$ & $0.80 \pm 0.34$ & 4.309 & $<0.001$ \\
\hline $\mathrm{HDL}-\mathrm{C}(\mathrm{mmol} / \mathrm{L})$ & $1.42 \pm 0.29$ & $1.32 \pm 0.29$ & $1.49 \pm 0.26$ & 16.974 & $<0.001$ \\
\hline LDL-C (mmol/L) & $2.1 \pm 0.56$ & $2.16 \pm 0.63$ & $2.05 \pm 0.50$ & 5.16 & $<0.001$ \\
\hline FPG (mmol/L) & $4.56 \pm 0.40$ & $4.52 \pm 0.39$ & $4.59 \pm 0.41$ & 5.134 & $<0.001$ \\
\hline Serum uric acid ( $\mu \mathrm{mol} / \mathrm{L})$ & $348.73 \pm 100.09$ & $422.77 \pm 90.84$ & $296.01 \pm 67.79$ & 42.016 & $<0.001$ \\
\hline Hyperuricemia, n (\%) & $903(29.7)$ & $600(47.4)$ & $303(17.0)$ & 326.492 & $<0.001$ \\
\hline Metabolic syndrome, n (\%) & $61(2.0)$ & $33(2.6)$ & $28(1.6)$ & 4.009 & 0.045 \\
\hline High physical activity, n (\%) & $886(29.1)$ & $539(42.6)$ & 347 (19.5) & 190.544 & $<0.001$ \\
\hline
\end{tabular}

\section{Prevalence of MetS and its components among SUA quartiles by gender}

Results showed that the BMI, WC, HP, WHR, SBP, DBP, TG, TC, LDL-C levels were progressively increased and HDL-C were progressively decreased across the SUA quartiles in both genders.

The participants were divided into 4 groups based on SUA levels (Q1: $\leq 359.15$; Q2: 359.16-410.25; Q3: 410.26472.55 and Q4: >472.55) in males. The prevalence of MetS, abdominal obesity, high blood pressure, high TG and low HDL-C showed a liner increased trend across the SUA quartiles $\left(P_{\chi 2}\right.$ trend $\left.=0.001\right)$. The detailed results were presented in Table 2. 
Table 2

Characteristics of the subjects according to SUA quartiles in males

\begin{tabular}{|c|c|c|c|c|c|c|}
\hline & Q1 & Q2 & Q3 & Q4 & $F / x^{2}$ & $P$ \\
\hline SUA $(\mu \mathrm{mol} / \mathrm{L})$ & $\leq 359.15$ & $\begin{array}{l}359.16- \\
410.25\end{array}$ & $\begin{array}{l}410.26- \\
472.55\end{array}$ & $>472.55$ & - & - \\
\hline Numbers (n) & 316 & 317 & 317 & 316 & - & - \\
\hline Age(years) & $18.80 \pm 1.16$ & $18.74 \pm 0.94$ & $18.62 \pm 0.81$ & $18.64 \pm 0.85$ & 2.526 & 0.056 \\
\hline Height (cm) & $\begin{array}{l}172.93 \pm \\
5.84\end{array}$ & $172.8 \pm 6.15$ & $\begin{array}{l}172.86 \pm \\
5.71\end{array}$ & $\begin{array}{l}173.17 \pm \\
6.47\end{array}$ & 0.221 & 0.882 \\
\hline Weight (kg) & $63.35 \pm 8.78$ & $\begin{array}{l}67.84 \pm \\
10.80\end{array}$ & $\begin{array}{l}69.45 \pm \\
11.26\end{array}$ & $\begin{array}{l}76.02 \pm \\
15.11\end{array}$ & 63.49 & $<0.001$ \\
\hline BMI $\left(\mathrm{kg} / \mathrm{m}^{2}\right)$ & $21.17 \pm 2.67$ & $22.72 \pm 3.47$ & $23.24 \pm 3.53$ & $25.32 \pm 4.65$ & 69.596 & $<0.001$ \\
\hline WC (cm) & $72.98 \pm 6.51$ & $76.37 \pm 8.44$ & $77.25 \pm 8.51$ & $\begin{array}{l}82.40 \pm \\
11.39\end{array}$ & 60.734 & $<0.001$ \\
\hline $\mathrm{HC}(\mathrm{cm})$ & $93.14 \pm 5.73$ & $95.68 \pm 6.80$ & $96.6 \pm 6.51$ & $99.79 \pm 8.22$ & 50.343 & $<0.001$ \\
\hline WHR & $0.78 \pm 0.04$ & $0.80 \pm 0.05$ & $0.80 \pm 0.05$ & $0.82 \pm 0.06$ & 32.802 & $<0.001$ \\
\hline SBP (mmHg) & $\begin{array}{l}119.15 \pm \\
12.37\end{array}$ & $\begin{array}{l}121.28 \pm \\
12.96\end{array}$ & $\begin{array}{l}122.03 \pm \\
13.64\end{array}$ & $\begin{array}{l}124.34 \pm \\
14.47\end{array}$ & 8.092 & $<0.001$ \\
\hline DBP (mmHg) & $\begin{array}{l}72.22 \pm \\
10.23\end{array}$ & $\begin{array}{l}73.20 \pm \\
10.77\end{array}$ & $\begin{array}{l}72.87 \pm \\
10.90\end{array}$ & $\begin{array}{l}75.23 \pm \\
11.91\end{array}$ & 4.428 & 0.004 \\
\hline TC (mmol/L) & $3.84 \pm 0.63$ & $3.93 \pm 0.63$ & $4.07 \pm 0.87$ & $4.24 \pm 0.73$ & 18.932 & $<0.001$ \\
\hline TG (mmol/L) & $0.74 \pm 0.29$ & $0.83 \pm 0.37$ & $0.87 \pm 0.44$ & $1.03 \pm 0.66$ & 22.202 & $<0.001$ \\
\hline $\mathrm{HDL}-\mathrm{C}$ (mmol/L) & $1.36 \pm 0.23$ & $1.34 \pm 0.27$ & $1.31 \pm 0.23$ & $1.24 \pm 0.23$ & 14.418 & $<0.001$ \\
\hline LDL-C (mmol/L) & $1.98 \pm 0.52$ & $2.07 \pm 0.53$ & $2.21 \pm 0.72$ & $2.39 \pm 0.64$ & 27.004 & $<0.001$ \\
\hline FPG (mmol/L) & $4.50 \pm 0.37$ & $4.53 \pm 0.37$ & $4.52 \pm 0.39$ & $4.53 \pm 0.41$ & 0.408 & 0.747 \\
\hline $\begin{array}{l}\text { Abdominal obesity, } n \\
(\%)\end{array}$ & $7(2.2)$ & $26(8.2)$ & $32(10.1)$ & 73 (23.1) & $75.565^{\star}$ & $<0.001$ \\
\hline $\begin{array}{l}\text { High blood pressure, } \\
\text { n (\%) }\end{array}$ & $96(30.4)$ & 103 (32.5) & 113 (35.6) & $137(43.4)$ & $13.393^{*}$ & $<0.001$ \\
\hline High TG, n (\%) & $4(1.3)$ & $8(2.5)$ & $14(4.4)$ & $41(13)$ & $52.764^{\star}$ & $<0.001$ \\
\hline Low HDL-C, n (\%) & $11(3.5)$ & $17(5.4)$ & $18(5.7)$ & $38(12.0)$ & $21.192^{\star}$ & $<0.001$ \\
\hline hyperglycemia, n (\%) & $1(0.3)$ & $2(0.6)$ & $3(0.9)$ & $5(1.6)$ & 3.217 & 0.359 \\
\hline MetS, n (\%) & $0(0.0)$ & $4(1.3)$ & $7(2.2)$ & $22(7.0)$ & $34.526^{\star}$ & $<0.001$ \\
\hline
\end{tabular}




\begin{tabular}{|lllllll|}
\hline & Q1 & Q2 & Q3 & Q4 & F/ $\chi^{2}$ & $P$ \\
\hline $\begin{array}{l}\text { High physical } \\
\text { activity, } \\
\mathrm{n}(\%)\end{array}$ & $128(40.5)$ & $127(40.1)$ & $135(42.6)$ & $149(47.2)$ & 4.079 & 0.253 \\
\hline * The values of the chi-square trend test. & & & & & \\
\hline
\end{tabular}

In females, the participants were divided into 4 groups based on SUA levels (Q1: $\leq 249.48 ;$ Q2: 249.49-289.15; Q3: 289.16-334.93 and Q4: >334.93). The prevalence of MetS, abdominal obesity, high TG and low HDL-C showed a liner increased trend across the SUA quartiles $\left(P_{\chi 2}\right.$ trend $\left.=0.001\right)$. The detailed results were presented in Table 3. 
Table 3

Characteristics of the subjects according to SUA quartiles in females

\begin{tabular}{|c|c|c|c|c|c|c|}
\hline & Q1 & Q2 & Q3 & Q4 & $F / x^{2}$ & $P$ \\
\hline SUA ( $\mu \mathrm{mol} / \mathrm{L})$ & $\leq 249.48$ & $\begin{array}{l}249.49- \\
289.15\end{array}$ & $\begin{array}{l}289.16- \\
334.93\end{array}$ & $>334.93$ & - & - \\
\hline Numbers (n) & 444 & 445 & 445 & 444 & - & - \\
\hline Age(years) & $18.67 \pm 0.93$ & $18.72 \pm 1.01$ & $18.67 \pm 0.94$ & $18.66 \pm 0.93$ & 0.346 & 0.792 \\
\hline Height (cm) & $\begin{array}{l}159.47 \pm \\
5.69\end{array}$ & $\begin{array}{l}159.87 \pm \\
5.39\end{array}$ & $\begin{array}{l}160.61 \pm \\
5.52\end{array}$ & $\begin{array}{l}159.97 \pm \\
5.49\end{array}$ & 3.249 & 0.021 \\
\hline Weight (kg) & $53.09 \pm 6.99$ & $53.84 \pm 7.26$ & $56.65 \pm 7.94$ & $\begin{array}{l}59.39 \pm \\
10.28\end{array}$ & 54.291 & $<0.001$ \\
\hline BMI $\left(\mathrm{kg} / \mathrm{m}^{2}\right)$ & $20.86 \pm 2.37$ & $21.05 \pm 2.51$ & $21.94 \pm 2.73$ & $23.19 \pm 3.77$ & 59.985 & $<0.001$ \\
\hline WC (cm) & $67.55 \pm 5.78$ & $67.85 \pm 5.79$ & $70.14 \pm 6.57$ & $72.34 \pm 8.52$ & 48.668 & $<0.001$ \\
\hline $\mathrm{HC}(\mathrm{cm})$ & $90.93 \pm 4.89$ & $91.29 \pm 5.18$ & $93.11 \pm 5.48$ & $94.70 \pm 6.86$ & 42.418 & $<0.001$ \\
\hline WHR & $0.74 \pm 0.05$ & $0.74 \pm 0.04$ & $0.75 \pm 0.05$ & $0.76 \pm 0.05$ & 16.808 & $<0.001$ \\
\hline SBP $(m m H g)$ & $\begin{array}{l}107.67 \pm \\
10.66\end{array}$ & $\begin{array}{l}107.83 \pm \\
10.59\end{array}$ & $\begin{array}{l}108.90 \pm \\
11.27\end{array}$ & $\begin{array}{l}110.19 \pm \\
11.62\end{array}$ & 4.953 & 0.002 \\
\hline DBP (mmHg) & $68.69 \pm 9.91$ & $\begin{array}{l}68.72 \pm \\
10.31\end{array}$ & $69.55 \pm 9.72$ & $70.43 \pm 9.55$ & 3.098 & 0.026 \\
\hline TC (mmol/L) & $4.04 \pm 0.60$ & $4.05 \pm 0.61$ & $4.11 \pm 0.63$ & $4.17 \pm 0.66$ & 4.315 & 0.005 \\
\hline TG (mmol/L) & $0.75 \pm 0.27$ & $0.77 \pm 0.31$ & $0.82 \pm 0.36$ & $0.87 \pm 0.42$ & 9.745 & $<0.001$ \\
\hline HDL-C (mmol/L) & $1.53 \pm 0.24$ & $1.51 \pm 0.27$ & $1.48 \pm 0.26$ & $1.45 \pm 0.28$ & 8.751 & $<0.001$ \\
\hline LDL-C (mmol/L) & $1.98 \pm 0.46$ & $1.99 \pm 0.48$ & $2.07 \pm 0.50$ & $2.17 \pm 0.53$ & 13.786 & $<0.001$ \\
\hline FPG (mmol/L) & $4.59 \pm 0.40$ & $4.60 \pm 0.42$ & $4.60 \pm 0.40$ & $4.58 \pm 0.45$ & 0.201 & 0.896 \\
\hline $\begin{array}{l}\text { Abdominal obesity, } n \\
(\%)\end{array}$ & $16(3.6)$ & $19(4.3)$ & $43(9.7)$ & 85 (19.1) & $72.106^{*}$ & $<0.001$ \\
\hline $\begin{array}{l}\text { High blood pressure, } \\
\text { n (\%) }\end{array}$ & $46(10.4)$ & $43(9.7)$ & $48(10.8)$ & $52(11.7)$ & 1.03 & 0.794 \\
\hline High TG, n (\%) & $3(0.7)$ & $5(1.1)$ & $7(1.6)$ & $16(3.6)$ & $11.041^{*}$ & 0.001 \\
\hline Low HDL-C, n (\%) & $69(15.5)$ & $99(22.2)$ & $103(23.1)$ & 140 (31.5) & $29.814^{\star}$ & $<0.001$ \\
\hline hyperglycemia, n (\%) & $4(0.9)$ & $5(1.1)$ & $4(0.9)$ & $7(1.6)$ & 1.219 & 0.748 \\
\hline MetS, n (\%) & $0(0.0)$ & $4(0.9)$ & $4(0.9)$ & $20(4.5)$ & $26.135^{\star}$ & $<0.001$ \\
\hline $\begin{array}{l}\text { High physical activity, } \\
\text { n (\%) }\end{array}$ & 75(16.9) & 86(19.3) & $91(20.4)$ & $95(21.4)$ & 3.203 & 0.361 \\
\hline
\end{tabular}




\section{Q1}

Q2

Q3

Q4

$F / \chi^{2}$

$P$

* The values of the chi-square trend test.

\section{Correlation Between Sua And Continuous Variables Of Mets Components}

In males, SUA levels was positively associated with WC $(r=0.301), \operatorname{SBP}(r=0.109), \mathrm{DBP}(r=0.111), \mathrm{TG}(r=$ $0.140)$, and was negatively associated with HDL $(r=-0.206)$. All $P$ values were less than 0.001 . In females, SUA levels was positively associated with WC $(r=0.379), \operatorname{SBP}(r=0.144), \mathrm{DBP}(r=0.092), \mathrm{TG}(r=0.254)$, and negatively associated with $\mathrm{HDL}(r=-0.134)$. All $P$ values were $<0.001$.

\section{Association Between Sua And Mets And Mets Components}

The prevalence of the MetS was too low among participants in the lowest quartile (cases $=0$ ) of the serum concentration of the uric acid. Therefore, we collapsed the 2 lowest quartiles of uric acid into a single reference group. After adjusted for age and obesity (based on BMI), the SUA showed a significant association with the prevalence of MetS in males (OR: 3.438, 95\% Cl: 1.090-10.841). Of the 5 components, after adjustment for age, obesity and the other components of the MetS as dichotomized variables, a positive association was observed between SUA and high TG in males (the highest quartile vs. the lowest 2 quartiles OR: 4.364, 95\% Cl: 2.1338.930).

In females, compared with the lowest 2 quartiles, the SUA was categorized in the 3rd quartile and the highest quartile showed a positive association with abdominal obesity prevalence after adjustment for age, obesity and the other components of the MetS as dichotomized variables, with the OR ( $95 \% \mathrm{Cl})$ were 1.976(1.1283.459) and 1.766(1.020-3.057), respectively. The data were presented in Table 4. 
Table 4

Adjusted odds ratios for MetS and components according to serum uric acid by gender

\begin{tabular}{|c|c|c|c|c|c|c|c|}
\hline & & & Q1 + Q2 & Q3 & & Q4 & \\
\hline & & & Reference & OR $(95 \% \mathrm{Cl})$ & $P$ & OR $(95 \% \mathrm{Cl})$ & $P$ \\
\hline \multirow[t]{12}{*}{ Males } & MetS & Crude & 1 & $\begin{array}{l}3.551(1.032- \\
12.221)\end{array}$ & 0.044 & $\begin{array}{l}11.767(4.019- \\
34.454)\end{array}$ & $<0.001$ \\
\hline & & Adjust* & 1 & $\begin{array}{l}1.932(0.528- \\
7.067)\end{array}$ & 0.32 & $\begin{array}{l}3.438(1.090- \\
10.841)\end{array}$ & 0.035 \\
\hline & High TG & Crude & 1 & $\begin{array}{l}2.391(1.093- \\
5.233)\end{array}$ & 0.029 & $\begin{array}{l}7.715(3.993- \\
14.909)\end{array}$ & $<0.001$ \\
\hline & & Adjust & 1 & $\begin{array}{l}1.912(0.848- \\
4.307)\end{array}$ & 0.118 & $\begin{array}{l}4.364(2.133- \\
8.930)\end{array}$ & $<0.001$ \\
\hline & Low HDL-C & Crude & 1 & $\begin{array}{l}1.301(0.708- \\
2.389)\end{array}$ & 0.397 & $\begin{array}{l}2.953(1.776- \\
4.91)\end{array}$ & $<0.001$ \\
\hline & & Adjust & 1 & $\begin{array}{l}0.935(0.496- \\
1.763)\end{array}$ & 0.835 & $\begin{array}{l}1.346(0.750- \\
2.415)\end{array}$ & 0.319 \\
\hline & $\begin{array}{l}\text { Abdominal } \\
\text { obesity }\end{array}$ & Crude & 1 & $\begin{array}{l}2.041(1.23- \\
3.387)\end{array}$ & 0.006 & $\begin{array}{l}5.462(3.527- \\
8.458)\end{array}$ & $<0.001$ \\
\hline & & Adjust ${ }^{+}$ & 1 & $\begin{array}{l}0.712(0.328- \\
1.547)\end{array}$ & 0.391 & $\begin{array}{l}0.966(0.479- \\
1.949)\end{array}$ & 0.924 \\
\hline & $\begin{array}{l}\text { High blood } \\
\text { pressure }\end{array}$ & Crude & 1 & $\begin{array}{l}1.208(0.909- \\
1.606)\end{array}$ & 0.193 & $\begin{array}{l}1.669(1.263- \\
2.206)\end{array}$ & $<0.001$ \\
\hline & & Adjust & 1 & $\begin{array}{l}1.022(0.760- \\
1.375)\end{array}$ & 0.884 & $\begin{array}{l}1.072(0.786- \\
1.462)\end{array}$ & 0.659 \\
\hline & Hyperuricemia & Crude & 1 & $\begin{array}{l}2.006(0.403- \\
9.998)\end{array}$ & 0.395 & $\begin{array}{l}3.376(0.802- \\
14.218)\end{array}$ & 0.097 \\
\hline & & Adjust ${ }^{+}$ & 1 & $\begin{array}{l}1.496(0.263- \\
8.509)\end{array}$ & 0.65 & $\begin{array}{l}1.481(0.268- \\
8.191)\end{array}$ & 0.653 \\
\hline \multirow[t]{6}{*}{ Females } & MetS & Crude & 1 & $\begin{array}{l}2.007(0.5- \\
8.062)\end{array}$ & 0.326 & $\begin{array}{l}10.436(3.545- \\
30.724)\end{array}$ & $<0.001$ \\
\hline & & Adjust* & 1 & $\begin{array}{l}1.231(0.288- \\
5.270)\end{array}$ & 0.779 & $\begin{array}{l}2.302(0.700- \\
7.572)\end{array}$ & 0.17 \\
\hline & High TG & Crude & 1 & $\begin{array}{l}1.76(0.634- \\
4.885)\end{array}$ & 0.278 & $\begin{array}{l}4.117(1.748- \\
9.695)\end{array}$ & 0.001 \\
\hline & & Adjust ${ }^{+}$ & 1 & $\begin{array}{l}1.421(0.500- \\
4.039)\end{array}$ & 0.51 & $\begin{array}{l}1.875(0.716- \\
4.908)\end{array}$ & 0.201 \\
\hline & Low HDL-C & Crude & 1 & $\begin{array}{l}1.293(0.98- \\
1.705)\end{array}$ & 0.069 & $\begin{array}{l}1.976(1.522- \\
2.567)\end{array}$ & $<0.001$ \\
\hline & & Adjust ${ }^{+}$ & 1 & $\begin{array}{l}1.119(0.839- \\
1.491)\end{array}$ & 0.445 & $\begin{array}{l}1.280(0.959- \\
1.708)\end{array}$ & 0.093 \\
\hline
\end{tabular}




\begin{tabular}{|c|c|c|c|c|c|c|}
\hline & & Q1 + Q2 & Q3 & & Q4 & \\
\hline \multirow[t]{2}{*}{$\begin{array}{l}\text { Abdominal } \\
\text { obesity }\end{array}$} & Crude & 1 & $\begin{array}{l}2.61(1.645- \\
4.141)\end{array}$ & $<0.001$ & $\begin{array}{l}5.777(3.824- \\
8.727)\end{array}$ & $<0.001$ \\
\hline & Adjust† & 1 & $\begin{array}{l}1.976(1.128- \\
3.459)\end{array}$ & 0.017 & $\begin{array}{l}1.766(1.020- \\
3.057)\end{array}$ & 0.042 \\
\hline \multirow[t]{2}{*}{$\begin{array}{l}\text { High blood } \\
\text { pressure }\end{array}$} & Crude & 1 & $\begin{array}{l}1.087(0.75- \\
1.575)\end{array}$ & 0.66 & $\begin{array}{l}1.192(0.83- \\
1.714)\end{array}$ & 0.342 \\
\hline & Adjust† & 1 & $\begin{array}{l}1.005(0.690- \\
1.463)\end{array}$ & 0.98 & $\begin{array}{l}0.938(0.637- \\
1.381)\end{array}$ & 0.746 \\
\hline \multirow[t]{2}{*}{ Hyperuricemia } & Crude & 1 & $\begin{array}{l}0.887(0.272- \\
2.896)\end{array}$ & 0.842 & $\begin{array}{l}1.566(0.579- \\
4.234)\end{array}$ & 0.376 \\
\hline & Adjust† & 1 & $\begin{array}{l}0.759(0.228- \\
2.528)\end{array}$ & 0.654 & $\begin{array}{l}1.193(0.407- \\
3.493)\end{array}$ & 0.748 \\
\hline
\end{tabular}

\section{Discussion}

In this cross-sectional study, the overall prevalence rate of hyperuricemia was $29.7 \%$, which was significantly more common in males than in females ( $47.6 \%$ vs. $17 \%)$. This rate was higher than those in most Asian epidemiological studies: Bangladesh, 9.3\% ${ }^{21}$; Japan, $25.8 \%{ }^{22}$; and Thailand, $10.6 \%{ }^{23}$. These disparities may be attributable to racial or ethnic differences. A more recent Thai study reported that the prevalence of hyperuricemia in men has reached $59 \%{ }^{24}$. Age differences may also partly explain this phenomenon. In the present study, the participants were young adults In a Spanish study, the prevalence rate of hyperuricemia in children was $53 \%{ }^{25}$. In China, students had high-intensity learning and accompanying high nutrition, including plenty of purine-rich foods in senior high school, which may lead to increased uric acid level and weight gain.

The results of the present study showed that the prevalence of MetS increased linearly in the quaternion of SUA, which confirmed the strong association between SUA level and MetS in Chinese young adults. These results were consistent with several epidemiological studies which reported in Asian population ${ }^{9,10}$, European population ${ }^{14,26}$, North American population ${ }^{27}$. After adjustment for confounding factors, SUA remained a risk factor for MetS in males. Low prevalence of MetS in the young participants may explain the possible reason. In a longitudinal study on Taiwanese adults, SUA seems an important predictor for the risk of incident MetS in $30-40$ years but not in 20-30 years age groups ${ }^{28}$. The mechanism for the positive association between SUA levels and MetS has not been fully elucidated, but some studies have suggested several possible explanations. Xanthine oxidoreductase (XOR) is a key enzyme in the formation of UA. It may participate in the pathogenesis of metabolic syndrome through oxidative stress and inflammation induced by XOR derived reactive oxygen species and $U A^{29}$. Animal experiments showed that XOR knockout mice could not produce UA, which led to the defect of fat accretion, suggesting that UA is involved in the adipogenesis ${ }^{30}$. Hyperuricemia has been demonstrated to impair nitric oxide generation and subsequent endothelial dysfunction ${ }^{31}$. Another 
important mechanism may be that hyperuricemia involved in insulin resistance through the production of reactive oxygen species and Deficiency of endothelial-formed nitric oxide ${ }^{32}$.

In addition, a positive association of SUA levels with low HDL-C and high TG was observed independent sex. However, the association with low HDL-C was no longer significant, whereas associated with high TG in males in multivariable regressions. This finding was partly similar to that of previous study which conducted among US children and adolescents ${ }^{33}$. In a survey of 234 male seafarers, SUA levels was associated with MetS and high TG ${ }^{34}$. Studies on the association between SUA levels and dyslipidemia were primarily conducted in elderly or middle-aged adults even though the results were controversial ${ }^{35-37}$. However, these results were likely to be disturbed by other confounding factors, such as chronic cardiovascular diseases and long-term medication. This observation indicated that SUA level might be a biomarker in the development of high TG in males.

Our results further found an association between SUA levels and abdominal obesity in females. The finding, which was more relevant to women, was similar to a Japanese study ${ }^{38}$. As we know, abdominal obesity is characterized by accumulation of visceral fat. Hikita et al. ${ }^{39}$ reported that SUA level was positively correlated with visceral fat area and subcutaneous fat area. According to a recent study, saliva UA has been proved to be an important marker of fat accumulation in adolescents ${ }^{40}$. Hyperuricemia reduces serum leptin levels, thereby inhibiting the decomposition of visceral fat and increasing the accumulation of TG in non-adipocytes, promoting the development of obesity ${ }^{41}$. Rats model experiments indicated that inhibition of UA production could block the conversion of fructose to TG in hepatocytes and reduce the accumulation of TG ${ }^{42}$. It is suggested that the increase of SUA level is involved in the occurrence and development of abdominal obesity.

Of the MetS components, high blood pressure showed an increased prevalence across the SUA levels in males, but the difference failed to reach statistical significance adjustment for other MetS components. This result is different from that shown by a 5-year cohort study, which indicated that hyperuricemia was associated with increased incidence rates of hypertension ${ }^{43}$. The difference might be attributed to the different subjects that subjects in our study were younger (18 to 26 years) than the reported study (30 to 85 years). Additionally, we adjusted abdominal obesity, hyperglycemia, high TG and low HDL-C that maybe interferes or modify this relationship. A Japanese cross-sectional study revealed that serum TG level may interfere with the relationship between SUA and prehypertension ${ }^{44}$. These results suggest that, if there are other metabolic factors or interactions interfere with or alter this relationship.

Our results should be interpreted in the context of potential limitations. Firstly, as it is a cross-sectional study, this study cannot prove the causal relationship between SUA and MetS and its components. Therefore, more prospective studies need to be conducted. Secondly, as the subjects of this study were young adults, the prevalence of hyperglycemia in females was $1.12 \%$ and $0.87 \%$ in males, and the prevalence of MetS in the total subjects was $2 \%$. This low prevalence may affect the confidence of the results. Finally, this study was conducted in a medical university and may not be applicable to other ethnic populations.

\section{Conclusions}


In present study, we confirmed that SUA level was positively associated with the prevalence of MetS and high TG in young male adults. In females, SUA was significantly associated with the prevalence of abdominal obesity. Additionally, more attention is necessary to examine the role of SUA in the pathogenesis of MetS.

\section{List Of Abbreviations}

SUA serum uric acid

MetS metabolic syndrome

BMI body mass indices

WC waist circumference

HC hip circumference

WHR Waist-hip ratio

HDL-C High-density lipoprotein cholesterol

LDL-C low-density lipoprotein cholesterol

TC total cholesterol

TG triglycerides

FPG fasting plasma glucose

SBP systolic blood pressure

DBP diastolic blood pressure

\section{Declarations}

\section{Ethics approval and consent to participate}

The study procedure was approved by the Scientific Research Institutiona Review Board of Wannan Medical College Yijishan Hospital, and was conducted in accordance with the Declaration of Helsinki. Written informed consent was obtained from all the participants.

\section{Consent for publication}

Not applicable.

\section{Availability of data and materials}

The datasets used and/or analysed during the current study are available from the corresponding author on reasonable request. 


\section{Competing interests}

The authors declare that they have no competing interests.

\section{Funding}

This work was supported by the National Natural Science Foundation of China (Grant No. 81874280), Key Research and Development Plan of Anhui Province (No. 1804h08020261), and Key Projects of Anhui Provincial Department of Education (No. KJ2019A0404, No. KJ2019A0405). The funding body had no role in study design, data collection, analysis, interpretation of data and preparation the manuscript.

\section{Authors' contributions}

Study concept and design: YYS and FZM. Subjects' collection: FZM, CY, ZLJ, HLP, JYL, and YYS. Acquisition and analysis of data: ZLJ and JYL. The drafting and writing of the manuscript: FZM and HLP. The revision of the manuscript: YYS and CY. All authors approved the final manuscript.

\section{Acknowledgements}

Not applicable

\section{References}

1. Grundy SM. Metabolic syndrome: a multiplex cardiovascular risk factor. J Clin Endocrinol Metab. 2007;92(2):399-404.

2. Gu D, Reynolds K, Wu X, et al. Prevalence of the metabolic syndrome and overweight among adults in China. Lancet. 2005;365(9468):1398-405.

3. Lu J, Wang L, Li M, et al. Metabolic Syndrome Among Adults in China: The 2010 China Noncommunicable Disease Surveillance. J Clin Endocrinol Metab. 2017;102(2):507-15.

4. Mottillo S, Filion KB, Genest J, et al. The metabolic syndrome and cardiovascular risk a systematic review and meta-analysis. J Am Coll Cardiol. 2010;56(14):1113-32.

5. Mannucci E, Monami M, Cresci B, et al. National Cholesterol Education Program and International Diabetes Federation definitions of metabolic syndrome in the prediction of diabetes. Results from the FIrenze-Bagno A Ripoli study. Diabetes Obes Metab. 2008;10(5):430-5.

6. Esposito K, Chiodini P, Colao A, Lenzi A, Giugliano D. Metabolic syndrome and risk of cancer: a systematic review and meta-analysis. Diabetes Care. 2012;35(11):2402-11.

7. Disease GBD, Injury I, Prevalence C. Global, regional, and national incidence, prevalence, and years lived with disability for 354 diseases and injuries for 195 countries and territories, 1990-2017: a systematic analysis for the Global Burden of Disease Study 2017. Lancet. 2018;392(10159):1789-858.

8. Jeong J, Suh YJ. Association between Serum Uric Acid and Metabolic Syndrome in Koreans. J Korean Med Sci. 2019;34(48):e307.

9. Ali N, Miah R, Hasan M, et al. Association between serum uric acid and metabolic syndrome: a crosssectional study in Bangladeshi adults. Sci Rep. 2020;10(1):7841. 
10. Nagahama K, Inoue T, Kohagura K, Ishihara A, Kinjo K, Ohya Y. Hyperuricemia predicts future metabolic syndrome: a 4-year follow-up study of a large screened cohort in Okinawa, Japan. Hypertens Res. 2014;37(3):232-8.

11. Scheepers L, Boonen A, Dagnelie PC, et al. Uric acid and blood pressure: exploring the role of uric acid production in The Maastricht Study. J Hypertens. 2017;35(10):1968-75.

12. Kodama S, Saito K, Yachi Y, et al. Association Between Serum Uric Acid and Development of Type 2 Diabetes. Diabetes Care.32(9):1737-1742.

13. Babio N, Martinez-Gonzalez MA, Estruch R, et al. Associations between serum uric acid concentrations and metabolic syndrome and its components in the PREDIMED study. Nutr Metab Cardiovasc Dis. 2015;25(2):173-80.

14. Cibickova L, Langova K, Vaverkova H, Kubickova V, Karasek D. Correlation of uric acid levels and parameters of metabolic syndrome. Physiol Res. 2017;66(3):481-7.

15. Duan Y, Liang W, Zhu L, et al. Association between serum uric acid levels and obesity among university students (China). Nutr Hosp. 2015;31(6):2407-11.

16. Kuwahara E, Murakami Y, Okamura T, et al. Increased childhood BMI is associated with young adult serum uric acid levels: a linkage study from Japan. Pediatr Res. 2017;81(2):293-8.

17. Wu Y, Huxley R, Li L, et al. Prevalence, awareness, treatment, and control of hypertension in China: data from the China National Nutrition and Health Survey 2002. Circulation. 2008;118(25):2679-86.

18. Kelishadi R, Majdzadeh R, Motlagh ME, et al. Development and Evaluation of a Questionnaire for Assessment of Determinants of Weight Disorders among Children and Adolescents: The Caspian-IV Study. Int J Prev Med. 2012;3(10):699-705.

19. Liu H, Zhang XM, Wang YL, Liu BC. Prevalence of hyperuricemia among Chinese adults: a national crosssectional survey using multistage, stratified sampling. J Nephrol. 2014;27(6):653-8.

20. Alberti KG, Eckel RH, Grundy SM, et al. Harmonizing the metabolic syndrome: a joint interim statement of the International Diabetes Federation Task Force on Epidemiology and Prevention; National Heart, Lung, and Blood Institute; American Heart Association; World Heart Federation; International Atherosclerosis Society; and International Association for the Study of Obesity. Circulation. 2009;120(16):1640-1645.

21. Ali N, Perveen R, Rahman S, et al. Prevalence of hyperuricemia and the relationship between serum uric acid and obesity: A study on Bangladeshi adults. PLoS One. 2018;13(11):e0206850.

22. Nagahama K, Iseki K, Inoue T, Touma T, Ikemiya Y, Takishita S. Hyperuricemia and cardiovascular risk factor clustering in a screened cohort in Okinawa, Japan. Hypertens Res. 2004;27(4):227-33.

23. Lohsoonthorn V, Dhanamun B, Williams MA. Prevalence of hyperuricemia and its relationship with metabolic syndrome in Thai adults receiving annual health exams. Arch Med Res. 2006;37(7):883-9.

24. Uaratanawong S, Suraamornkul S, Angkeaw S, Uaratanawong R. Prevalence of hyperuricemia in Bangkok population. Clin Rheumatol. 2011;30(7):887-93.

25. Civantos Modino S, Guijarro de Armas MG, Monereo Mejias S, et al. Hyperuricemia and metabolic syndrome in children with overweight and obesity. Endocrinol Nutr. 2012;59(9):533-8.

26. Petrikova J, Janicko M, Fedacko J, et al. Serum Uric Acid in Roma and Non-Roma-Its Correlation with Metabolic Syndrome and Other Variables. Int J Environ Res Public Health. 2018;15(7). 
27. Coutinho Tde A, Turner ST, Peyser PA, Bielak LF, Sheedy PF 2nd, Kullo IJ. Associations of serum uric acid with markers of inflammation, metabolic syndrome, and subclinical coronary atherosclerosis. Am J Hypertens. 2007;20(1):83-9.

28. Chen YY, Kao TW, Yang HF, et al. The association of uric acid with the risk of metabolic syndrome, arterial hypertension or diabetes in young subjects- An observational study. Clin Chim Acta. 2018;478:68-73.

29. Battelli MG, Bortolotti M, Polito L, Bolognesi A. The role of xanthine oxidoreductase and uric acid in metabolic syndrome. Biochim Biophys Acta Mol Basis Dis. 2018;1864(8):2557-65.

30. Cheung KJ, Tzameli I, Pissios P, et al. Xanthine oxidoreductase is a regulator of adipogenesis and PPARgamma activity. Cell Metab. 2007;5(2):115-28.

31. Khosla UM, Zharikov S, Finch JL, et al. Hyperuricemia induces endothelial dysfunction. Kidney Int. 2005;67(5):1739-42.

32. Meshkani R, Zargari M, Larijani B. The relationship between uric acid and metabolic syndrome in normal glucose tolerance and normal fasting glucose subjects. Acta Diabetol. 2011;48(1):79-88.

33. Ford ES, Li C, Cook S, Choi HK. Serum concentrations of uric acid and the metabolic syndrome among US children and adolescents. Circulation. 2007;115(19):2526-32.

34. Baygi F, Herttua K, Sheidaei A, Ahmadvand A, Jensen OC. Association of Serum Uric Acid with cardiometabolic risk factors and metabolic syndrome in seafarers working on tankers. BMC Public Health. 2020;20(1):442.

35. Sumiyoshi H, Ohyama Y, Imai K, Kurabayashi M, Saito Y, Nakamura T. Association of Uric Acid with Incident Metabolic Syndrome in a Japanese General Population. Int Heart J. 2019;60(4):830-5.

36. Techatraisak K, Kongkaew T. The association of hyperuricemia and metabolic syndrome in Thai postmenopausal women. Climacteric. 2017;20(6):552-7.

37. Choi H, Kim HC, Song BM, et al. Serum uric acid concentration and metabolic syndrome among elderly Koreans: The Korean Urban Rural Elderly (KURE) study. Arch Gerontol Geriatr. 2016;64:51-8.

38. Tani S, Matsuo R, Imatake K, et al. The serum uric acid level in females may be a better indicator of metabolic syndrome and its components than in males in a Japanese population. J Cardiol. 2020;76(1):100-8.

39. Hikita M, Ohno I, Mori Y, Ichida K, Yokose T, Hosoya T. Relationship between hyperuricemia and body fat distribution. Internal medicine. 2007;46(17):1353-8.

40. Araujo DS, Scudine KGO, Pedroni-Pereira A, et al. Salivary uric acid is a predictive marker of body fat percentage in adolescents. Nutrition research. 2020;74:62-70.

41. Obeidat AA, Ahmad MN, Haddad FH, Azzeh FS. Leptin and uric acid as predictors of metabolic syndrome in jordanian adults. Nutr Res Pract. 2016;10(4):411-7.

42. Sanchez-Lozada LG, Andres-Hernando A, Garcia-Arroyo FE, et al. Uric acid. activates aldose reductase. and the polyol pathway for endogenous fructose and fat production causing development of fatty liver in rats. J Biol Chem. 2019;294(11):4272-81.

43. Kuwabara M, Niwa K, Hisatome I, et al. Asymptomatic Hyperuricemia Without Comorbidities Predicts Cardiometabolic Diseases: Five-Year Japanese Cohort Study. Hypertension. 2017;69(6):1036-44. 
44. Kawamoto R, Tabara Y, Kohara K, Kusunoki T, Abe M, Miki T. Interaction between serum uric acid and triglycerides in relation to prehypertension in community-dwelling Japanese adults. Clin Exp Hypertens. 2014;36(1):64-9.

\section{Supplementary Files}

This is a list of supplementary files associated with this preprint. Click to download.

- Questionnaire.docx

- STROBEChecklist.doc 